\title{
A Phyllodromica transylvanica VIDLIČKA, 1994 (Blattodea, Blattellidae) Magyarországon
}

\author{
KinÁl FERENC ${ }^{1}$ és PuSKás GellérT ${ }^{2}$ \\ ${ }^{1}$ E-mail: fkinalf.ferenc@gmail.com \\ ${ }^{2}$ Magyar Természettudományi Múzeum Állattára, 1088 Budapest, \\ Baross utca 13. E-mail: puskas.gellert@nhmus.hu
}

Összefoglalás. Bátorliget környékéről a korábban ismert Ectobius lapponicus mellett három újabb erdeicsótány faj jelenlétét mutattuk ki: Ectobius erythronotus nigricans, Phyllodromica megerlei és Phyllodromica transsylvanica. Az utóbbi fajnak ez az első adata Magyarország területéröl. Az újabb fajjal együtt hazánkban hét Phyllodromica faj jelenléte ismert.

Kulcsszavak: erdeicsótány, faunisztika, Bátorliget, fajlista.

\section{Bevezetés}

Az erdeicsótányok (Blattellidae: Ectobiinae, egyes rendszerek szerint Ectobiidae család) a csótányok egyetlen olyan csoportja, amelynek fajai a szabadban élnek Magyarországon. Közülük hazánkban ezidáig négy Ectobius és hat Phyllodromica faj előfordulását jelezték (VIDLIČKA \& SZIRÁKI 1997, BOHN \& CHLÁDEK 2011). Utóbbi genusz - az avarcsótányok palearktikus elterjedésü, jelenleg 98 érvényes leírt fajjal (BECCALONI 2018). A maculata fajcsoport sötét színü, melegkedvelő fajokat foglal magába, fedőszárnyukon feltűnő fekete foltot viselnek (BOHN \& CHLÁDEK 2011). Közép-Európában összesen kilenc fajuk fordul elö, amelyek többségét a 70-es évektől a közelmúltig fedezték fel (HARZ 1977, CHLÁDEK \& HARZ 1977, CHLÁDEK \& HARZ 1980, VIDLIČKA 1993, 1994, CHLÁDEK 1996, BOHN \& CHLÁDEK 2011).

Az egyik erdélyi endemizmusnak tartott faj a Phyllodromica transylvanica. E fajt L'UBOMÍR VIDLIČKA írta le KIS BÉLA Kolozsvár környékén gyüjtött példányai alapján (Románia, Cluj-Napoca, $2 \widehat{\jmath}$ ô, 2 + 9 imágó, 1966.VII.1.) (VIDLIČKA 1994). 2009-ben további 19 erdélyi lelőhelyről jelezték az előfordulását, amiből arra lehet következtetni, hogy ez a faj - legalábbis Erdélyben - eléggé általános előfordulású (BOHN \& CHLÁDEK 2011) (1. ábra). 


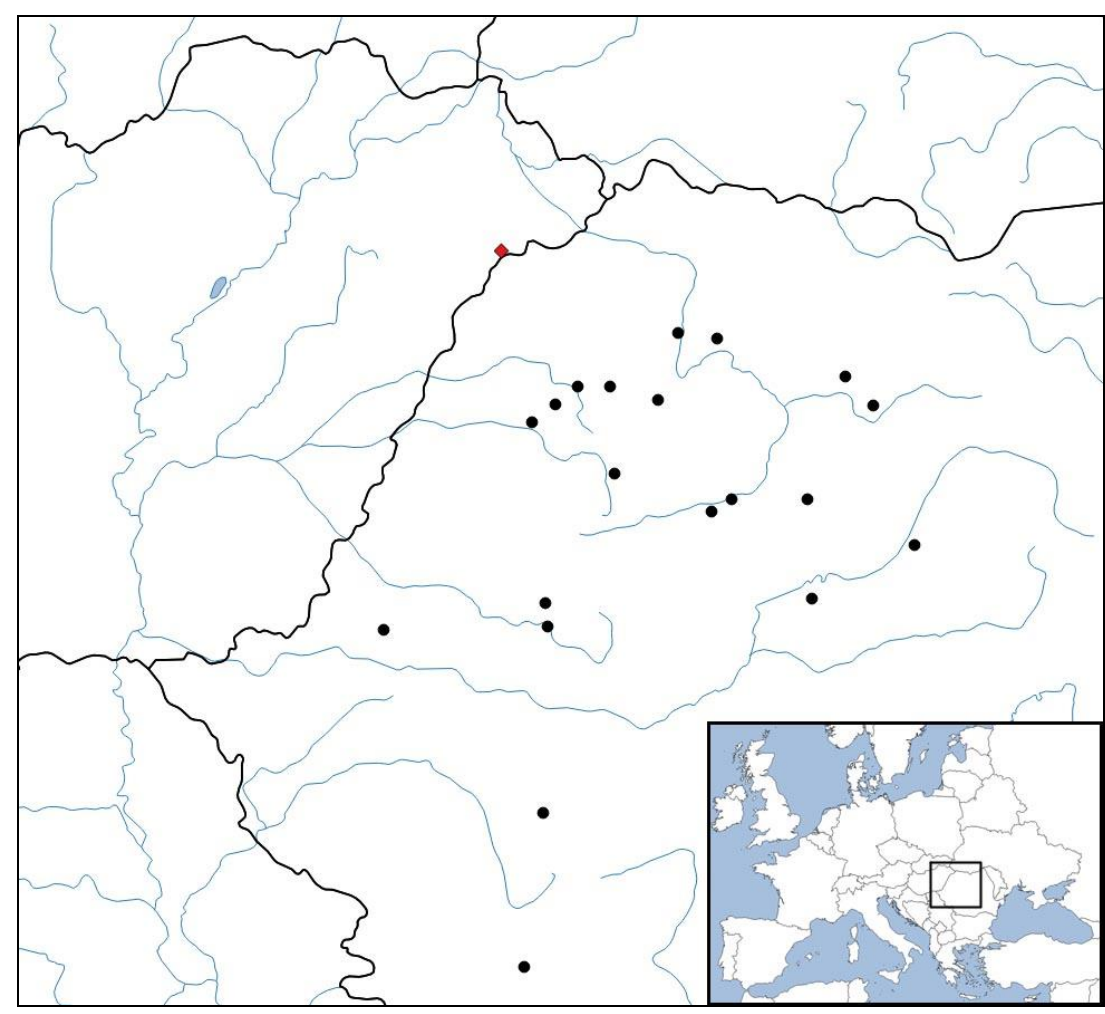

1. ábra. A Phyllodromica transylvanica elterjedése BOHN \& CHLÁDEK (2011) alapján, kiegészítve a magyarországi gyüjtési hellyel (Bátorliget, Fényi-erdő, szögletes jelölő).

Figure 1. Distribution of Phyllodromica transylvanica (modified after BOHN \& CHLÁDEK 2011). The square mark shows the new locality near Bátorliget, Hungary.

\section{Anyag és módszer}

A 2011. évi gyüjtések a Magyar Biodivezitás-kutató Társaság által szervezett VII. Magyar Biodiverzitás Napok keretében történtek (Bátorliget, Fényi-erdő, 2011. május 27-29). A programban részt vevő kutatók feladata a kijelölt területrészek diverzitásának felmérése nagyjából 24 óra alatt az ott fellelhető célcsoportok (állatok, növények, gombák) összesített fajszáma alapján.

A 2011-ben gyüjtött anyag feldolgozása után a Magyar Természettudományi Múzeum Állattárában őrzött, Bátorliget környékéről származó publikálatlan csótány anyagot is megvizsgáltuk. Ez LOKSA IMRE (1923-1992), az Eötvös Loránd Tudományegyetem Állatrendszertani és Ökológiai Tanszékének egykori vezetője folyadékban konzervált és nagyrészt feldolgozatlan talajcsapda anyagából származik, amely 2017-ben került a múzeum gyüjteményeibe. 
A Phyllodromica transylvanica faj pontos azonosítását BOHN \& CHLÁDEK (2011) revíziós munkája alapján végeztük el.

A mikroszkópos fotók Olympus SZX9 sztereomikroszkóp és Olympus Camedia C-4040 200M (4,1Mp.) digitális fényképezőgép segítségével készültek.

A 2011-ben gyüjtött példányok szárazon preparált állapotban KINÁL FERENC gyüjteményében lettek elhelyezve, míg az 1991-es talajcsapdás anyagok maradtak a Magyar Természettudományi Múzeum Állattárában (Kisebb rovarrendek gyüjteménye), alkoholban konzerválva.

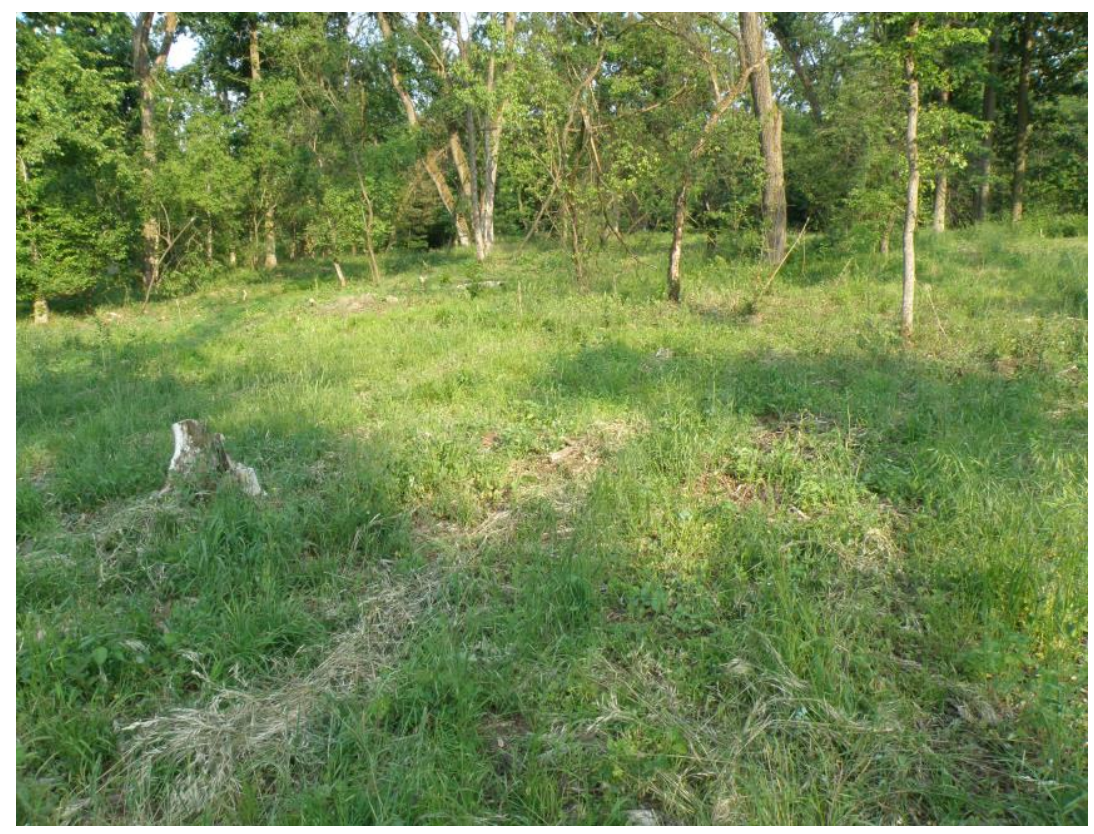

2 ábra. Ligetes tölgyes Bátorliget, Fényi-erdő területén, az Ectobius erythronotus nigricans élöhelye. Figure 2. Open oak forest near Bátorliget, Fényi forest (E Hungary), biotope of Ectobius erythronotus nigricans.

\section{Faunisztikai eredmények}

Ectobius erythronotus nigricans RAMME, 1923

Bátorliget, Fényi-erdő, fiatal tölgyes erdőszél, Rubus, Urtica füves bozót (2. ábra), N47,7437 E22,2665, egyelés, 2011. V. 27, leg. KINÁL F. (1つ̂ imágó) 


\section{Ectobius sp.}

„Fény 991 II.; 6” (2 fejlett lárva): Bátorliget, Fényi-erdő, tisztás buckán, saspáfrányos gyep, talajcsapda 1991. április 9-től ismeretlen időpontig, leg. LOKSA I. (faji szinten nem határozható).

Phyllodromica transylvanica VIDLIČKA, 1994 - Magyaroszág faunájára új faj.

Bátorliget, Fényi-erdő, fiatal tölgyes, jórészt Carex borította higro-mezofil tisztás-rét (3.

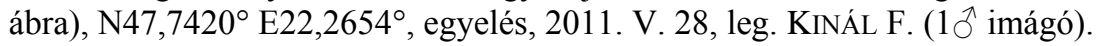

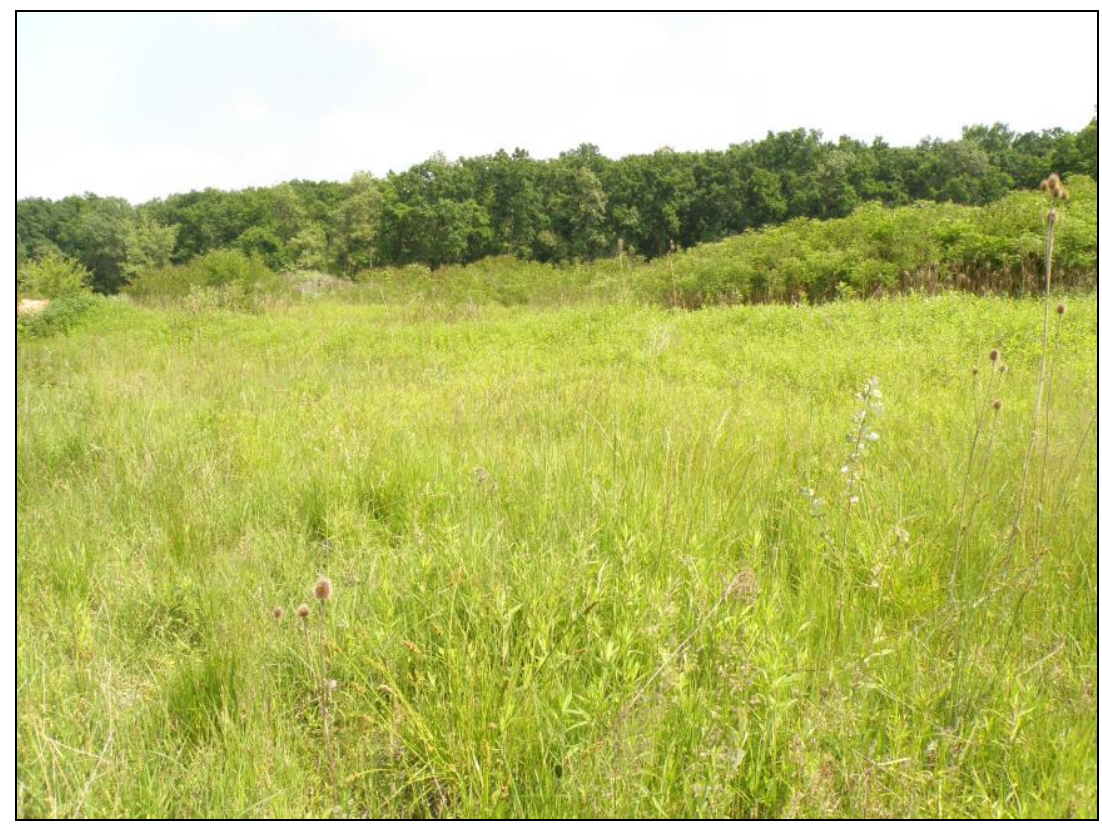

3 ábra. Mezo-higrofil rét Bátorliget, Fényi-erdő területén, a Phyllodromica transylvanica élőhelye. Figure 3. Meso-hygrophilic meadow near Bátorliget, Fényi forest (E Hungary), biotope of Phyllodromica transylvanica.

Bátorliget, Fényi-erdő, xeromezofil, akácos széli gyep (4. ábra), N47,7440 E22,2679² egyelés, 2011. V. 28, leg. KINÁL F. (3ổ ês 1 iq imágó)

„Fény 991 II.; 6” (1ㅇ, 11 fejlett lárva) - a cédulán szereplő kódok legvalószínübb megfejtése LOKSA IMRE gyüjtőnaplói alapján: Bátorliget, Fényi-erdő, tisztás buckán, saspáfrányos gyep, talajcsapda 1991. április 9-től ismeretlen időpontig, leg. LOKSA I. 
Phyllodromica megerlei FIEBER, 1853

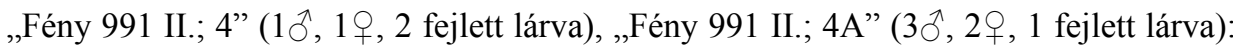
Bátorliget, Fényi-erdő, buckai tisztás szegélyén saspáfrányos, talajcsapda 1991. április 9-töl ismeretlen időpontig, leg. LOKSA I.

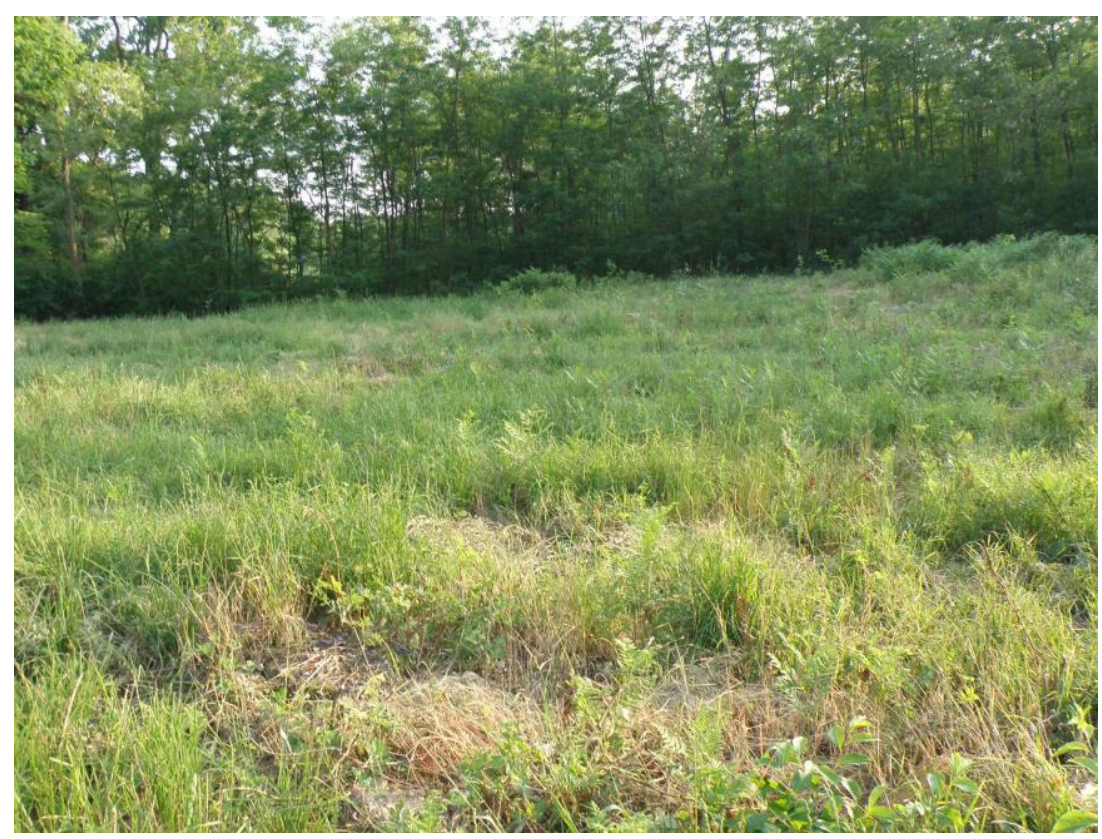

4 ábra. Akácos-széli biotóp Bátorliget, Fényi-erdő területén, a Phyllodromica transylvanica élőhelye.

Figure 4. Xero-mesophilic meadow at a Robinia pseudoacacia plantation near Bátorliget, Fényi forest (E Hungary), biotope of Phyllodromica transylvanica.

\section{Értékelés}

Bátorligetről ezidáig mindössze egyetlen Ectobiinae faj volt ismert, az Ectobius lapponicus (LinNAEUS, 1758) (NAGY 1991). Ezen kívül ugyan említés történik az E. sylvestris (PODA, 1761) fajról is (VIDLIČKA \& SZIRÁKI 1997), ez azonban téves hivatkozásnak tünik, mert az idézett cikkben (NAGY 1991) csak az E. lapponicus faj szerepel, mégpe-

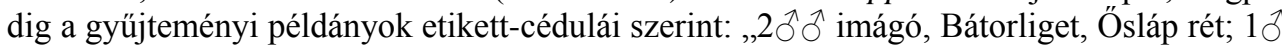
imágó (utóbbi potroha hiányzik), rezervátum erdőszegély nyiladék, 1988. VI. 30, leg.: NAGY B".

Az újabb adatokkal együtt tehát Bátorliget környékén jelenleg négy erdeicsótány faj jelenlélte ismert. 


\section{A Phyllodromica transylvanica faj Magyarországon}

Javasolt magyar név: erdélyi avarcsótány.

A határozáshoz fontos bélyegek

Mikroszkópon át készített felvételek mutatják az egyik gyüjtött đ̋ alapján a határozáshoz fontos részleteket (5. ábra). Ezek az elülső- és hátulsó szárnyak, valamint a potroh 7. és utolsó hátlemezének formája.

A đolülső szárnya a csúcsa felé keskenyedik, szüken, és nem szélesen lekerekített, egyenletesen ívelt, töve nem vállszerü. Széles hosszanti sötét sáv húzódik rajta, ami a szárnycsúcs felé keskenyedik. A sugárér ágai jól láthatóak (5/A ábra). A hátulsó szárny nem kifliszerüen hajlott, elülső széle ívelt, csúcsa rövid (5/B ábra). A potroh illatmirigye felett ívelö 7. hátlemeze középen hosszanti irányban nem osztott. Az utolsó hátlemez (szupraanális lemez) hátulsó széle nem csúcsos (5/C ábra).

A + elülső szárnyán folyamatosan szükülő hosszanti szalag húzódik, ami nem éri el a szárnycsúcsot. Hátulsó szárnya rövid csúcsot visel, ami szöget zár be az anális mező hajtásával, és nem áll azzal egyvonalban.

A gyüjtött példányokon felvett legfontosabb méreteket az 1. táblázat mutatja.

1. táblázat. A vizsgált Phyllodromica transylvanica példányok testméretei (mm).

Table 1. Dimensions of the studied Phyllodromica transylvanica specimens (in $\mathrm{mm}$ ).

\begin{tabular}{lcc} 
& $\hat{\jmath} \mathbf{( N = 4 )}$ & q $\mathbf{( N = 2 )}$ \\
\hline testhossz / body length & $7,1(6,7-7,6)$ & $7,1(6,7-7,4)$ \\
előhát hossz / length of pronotum & $2,3(2,2-2,4)$ & $2,5(2,5)$ \\
előhát szélesség / width of pronotum & $3,0(2,9-3,0)$ & $2,9(2,9)$ \\
elülső szárny hossz / length of tegmina & $5,7(5,6-5,9)$ & $3,4(3,3-3,5)$ \\
elülső szárny szélesség / width of tegmina & $2,2(2,2)$ & $2,3(2,3)$ \\
hátulsó szárny hossz / length of hind wing & $1,5(1,5)$ & $1,5(1,4-1,5)$
\end{tabular}




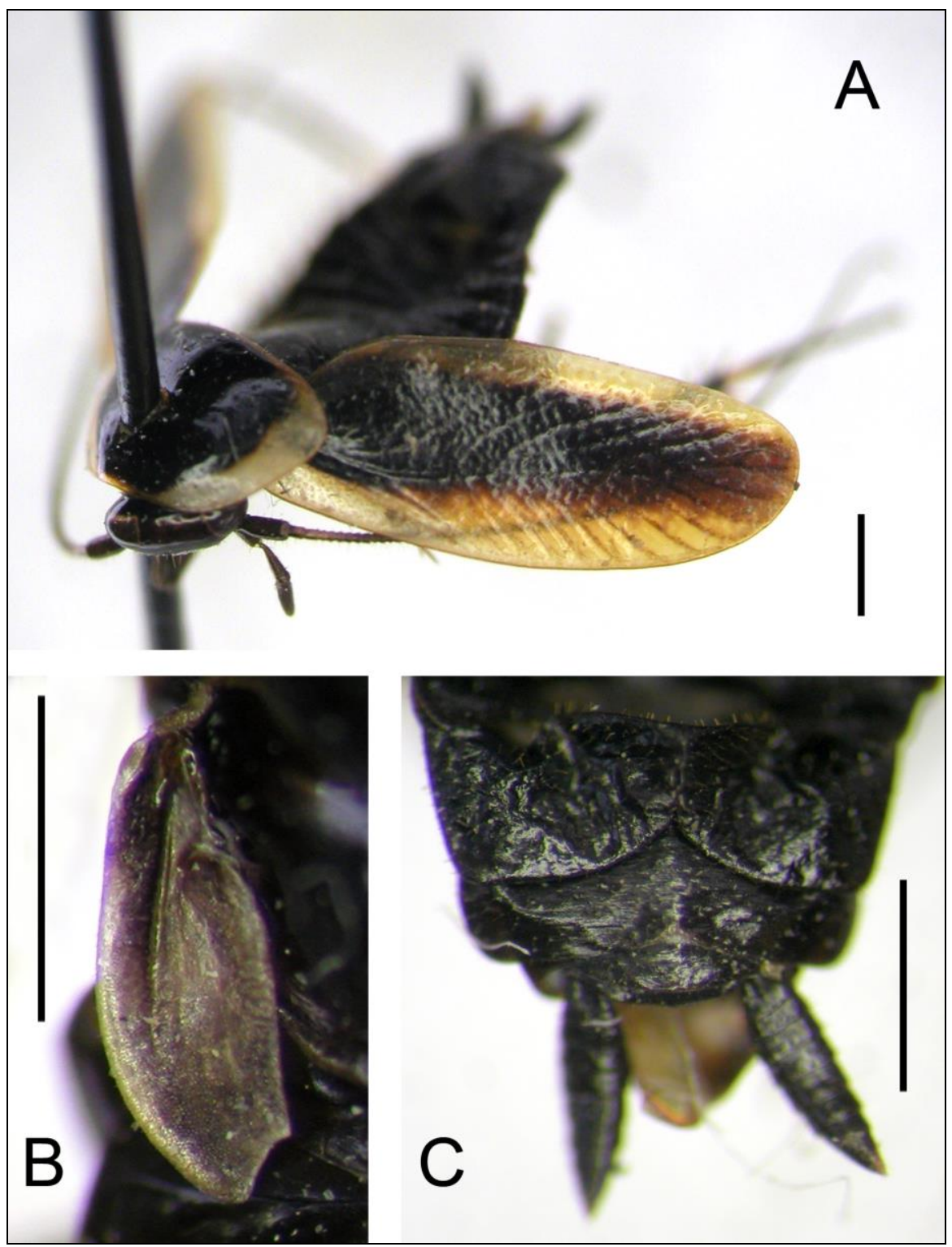

5. ábra. A $\widehat{\jmath}$ Phyllodromica transylvanica legfontosabb határozóbélyegei. A: teljes alak a bal elülső szárnnyal; B: bal hátsó szárny; C: potroh-vég felülnézetben a 7. szelvénytől (Bátorliget, Fényi-erdő, akácos-széli gyepből). Skála: $1 \mathrm{~mm}$.

Figure 5. Most important morphological characters of $\hat{o}$ Phyllodromica transylvanica A: full body with the left tegmen; B: left hindwing; C: abdomen from the 7th tergite (Bátorliget, Hungary). Scale bar: $1 \mathrm{~mm}$. 
Élöhely

Az egyeléssel gyüjtött erdeicsótány példányok lelöhelyei a Fényi-erdő Bátorliget községhez közel eső északi sávjába esnek, ahol a zárt erdőt szántók és fiatalos erdőparcellák tagolják. A növényzet alkotói között szerepel ligeterdő kiszáradt és élő hagyásfákkal (föleg Quercus robur), xeromezofil gyeppel (Bromus, Dactylis, Urtica, Chelidonium), fiatal akácos ültetvény, higro-mezofil rét, (föleg Carex, szélein Populus, Amorpha) és mindenhová benyomuló Solidago is. Bátorliget, Fényi-erdő növényzetét részletesen RÉV et al. (2006) ismerteti.

Az elsőként talált hím $P$. transylvanica példány élőhelyén (tölgyes tisztáson higromezofil rét) a növényzeti borítás $100 \%$-os, $40 \mathrm{~cm}$ magas, $90 \%$-ban sás alkotta (3. ábra). Ezen a helyen állt az előző napi egyik rovar-lámpázóhely, a példányt valószínüleg a rovarmaradványok csalhatták oda.

A második lelöhelyen (akácos széli gyep) a növényzeti borítottsága $50-80 \%$-os és $80 \mathrm{~cm}$ magas, 80\%-ban Gramineae fajok alkották, a talaját régi lomb és száraz fü borította (4. ábra).

\section{Magyarországi helyzet}

A faj jelenleg ismert előfordulási adatai alapján (1. ábra) valószínüsíthető, hogy az Erdély nagy részét lefedő, délen a Mehádiai hegységig húzódó areának csupán az északnyugati szegélye érinti Magyarország területét. A bátorligeti példányok a faj ismert elterjedési területének legészakibb pontját jelölik ki.

A rendkívül kevés ismeret miatt nehéz megítélni a faj magyarországi állományának méretét, természetvédelmi helyzetét. A Fényi-erdő a Nyírség egykor kiterjedt erdőségeinek egyik utolsó fragmentuma, ahol az utóbbi évtizedekben minőségi szegényedés volt tapasztalható a növényzet fajkészletében (RÉV et al. 2006). Megfelelő élőhelykezelések esetén azonban valószínü, hogy a Fényi Erdő Természetvédelmi Terület illetve a Fényi-erdő Erdőrezervátum megőrizheti faunánknak ezt a színezőelemét. A $P$. transylvanica hazai elterjedésének és életmódjának megismeréséhez további vizsgálatokra van szükség.

Az utóbbi évtizedekben az Alföld keleti pereméröl az Orthoptera rendböl több, részben erdélyi előfordulású faj került elő. Ezek közül példaképpen említhető az Isophya stysi, Leptophyes discoidalis és a Pholidoptera littoralis szöcskék (NAGY \& SZÖVÉNYI 1999), az Odontopodisma rubripes sáska (NAGY 1953, NAGY et al. 2010) valamint a Modicogryllus truncatus tücsök (SZÖVÉNYI 2011) újabb keletủ megtalálása. Ezek többsége viszonylag nagy testü rovar, amelyek szintén a kelet-magyarországi régió alulkutatottsága miatt maradhattak sokáig ismeretlenek.

A hazai Phyllodromica fajok jegyzéke

Az újabb adattal együtt Magyarország területéről hét avarcsótány faj ismert:

Phyllodromica maculata fajcsoport

1. Phyllodromica harzi CHLÁDEK, 1977 - Harz-avarcsótány

2. Phyllodromica hungarica VIDLIČKA, 1993 - magyar avarcsótány

3. Phyllodromica latipennis BOHN \& CHLÁDEK, 2011 - szélesszárnyú avarcsótány

4. Phyllodromica maculata (SCHREBER, 1781) - foltos avarcsótány 
5. Phyllodromica marani CHLÁDEK \& HARZ, 1980 - Mařan-avarcsótány

6. Phyllodromica transylvanica VIDLIČKA, 1994 - erdélyi avarcsótány

Phyllodromica megerlei fajcsoport

7. Phyllodromica megerlei FIEBER, 1853 - pontozott avarcsótány

Köszönetnyilvánítás. Köszönjük KovÁcs TiBORnak (Magyar Biodiverzitás-kutató Társaság) a Magyar Biodiverzitás Napok megszervezését, amely lehetővé tette a gyüjtéseket. NAGY BARNABÁS (Magyar Természettudományi Múzeum) a cikk elkészítéséhez nyújtott értékes tanácsokat, HORVÁTH EDIT (Magyar Természettudományi Múzeum) LOKSA IMRE gyűjtőhelyeinek azonosításában volt segítségünkre. Építő kritikájukért hálásak vagyunk MURÁNYI DÁviDnak (Magyar Tudományos Akadémia, Növényvédelmi Intézet) és a kézirat másik, anonim lektorának.

\section{Irodalomjegyzék}

BecCAloni, G. W. (2018): Cockroach Species File Online. Version 5.0/5.0. World Wide Web electronic publication. http://Cockroach.SpeciesFile.org (megtekintés 2018. febr. 13.)

Bohn, H. \& CHLÁDEK, F. (2011): Revision of the maculata-group of Phyllodromica: species from Central Europe (Insecta: Blattodea: Blattellidae: Ectobiinae). Arthropod Systematics \& Phylogeny 69: 3-54.

Chládek, F. (1996): Phyllodromica dobsiki sp. nov. aus der Slowakei (Blattoptera, Ectobiidae, Ectobiinae). Selene 5: 5-9.

ChlÁdeK, F. \& HARZ, K. (1977): Zwei neue Phyllodromica-Arten aus der Slowakei. Articulata 1(4): $21-24$

CHLÁDEK, F. \& HARZ, K. (1980): Zur Variabilität der Oothek von Phyllodromica maculata (Schreb.) (Blattoptera). Articulata 1(16): 176-178.

Harz, K. (1976): Ordnung Blattoptera. In: Harz, K. \& KaltenbaCh, A. (eds): Die Orthopteren Europas, Band 3. Junk, The Hague, pp. 169-305.

Nagy, A., Kisfali, M., SzÖvÉnYI, G., Puskás, G. \& RÁCZ, I. A. (2010): Distribution of Catantopinae species (Orthoptera: Acrididae) in Hungary. Articulata 25(2): 221-237.

NAGY, B. (1953): Bátorliget egyenesszárnyú faunája. Orthoptera-Saltatoria. In: SzÉKESSY V. (szerk.): Bátorliget élővilága. Akadémiai Kiadó, Budapest, pp. 187-193.

NAGY, B. (1991): Orthopteroid insects (Orthoptera, Mantodea, Blattodea, Dermaptera) of the Bátorliget Nature reserves (NE Hungary). (An ecofaunistic account). In: MAHUNKA, S. (ed.): Bátorliget Nature reserve - after forty years - Volume 1. Hungarian Natural History Museum, Budapest, pp. 295-318

NAGY, B. \& SzÖVÉNYI, G. (1999): Erdélyi - balkáni hatások a Fekete-Körös erdős vidékének Orthoptera faunájában. Crisicum 2: 123-131.

RÉv, Sz. , PAPP, M., Lesku, B. \& BudAy, A. (2005): A bátorligeti Fényi-erdõ flórája. Kitaibelia 10 (1): 48-64.

SZÖVÉNYI, G. (2011): First record of Modicogryllus truncatus in Hungary (Orthoptera: Gryllidae). Folia Entomologica Hungarica 72: 9-12. 
VIDLIČKA, L. (1993): Phyllodromica hungarica sp. nov., a new cockroach species from Hungary (Insecta: Blattodea: Blattellidae: Ectobiinae). Entomological Problems 24(1): 63-68.

VIDLIČKA, L. (1994): Phyllodromica transylvanica sp. nov., a new cockroach species from Romania and key of the maculata group of Phyllodromica in central Europe (Blattaria: Blattellidae: Ectobiinae). Entomological Problems 25(2): 55-62.

VIDLIČKA, L. \& SzIRÁKI, Gy. (1997): The native cockoroaches (Blattaria) in the Carpathian Basin. Folia Entomologica Hungarica 58: 187-220. 


\section{First record of Phyllodromica transylvanica Vidlička, 1994 (Blattodea,} Blattellidae) in Hungary

\section{FERENC KINÁL ${ }^{1}$ \& GELLÉRT PUSKÁS ${ }^{2}$}

${ }^{1}$ E-mail: fkinalf.ferenc@gmail.com

${ }^{2}$ Hungarian Natural History Museum, Department of Zoology, Baross u.13,

H-1088 Budapest, Hungary E-mail: puskas.gellert@nhmus.hu

\section{ÁLLATTANI KÖZLEMÉNYEK (2018) 103(1-2): 3-13.}

Abstract. Phyllodromica transylvanica is reported first time from Hungary (Bátorliget, Fényi forest), near the state border with Romania. This species earlier was known to be endemic in the latter country. We give detailed descriptions about the collecting sites and about the morphology of the collected specimens. With the newly found species altogether seven Phyllodromica species are known from the territory of Hungary.

Altogether four Blattellidae: Ectobiinae species were detected in the Bátorliget Nature Reserves (East Hungary). Besides the previously known Ectobius lapponicus, three further species were found during this study: Ectobius erythronotus nigricans, Phyllodromica megerlei and Phyllodromica transylvanica.

Keywords: cockroach, faunistics, Bátorliget, national check-list. 